\title{
Biochemical and molecular-genetic markers of adaptability and quality of genotypes in cultural and wild cereal plants
}

\author{
V. V. Moskalets ${ }^{1}$, A. H. Vovkohon ${ }^{2}$, M. M. Kliuchevych ${ }^{3}$, T. Z. Moskalets* ${ }^{1}$, \\ A. O. Sliusarenko ${ }^{2}$, V. V. Liubych ${ }^{4}$, A. T. Martyniuk ${ }^{4}$, O. S. Pushka ${ }^{4}$, I. M. Pushka ${ }^{4}$, \\ V. I. Nevlad ${ }^{4}$ \\ ${ }^{1}$ Institute of Horticulture, National Academy of Agrarian Science of Ukraine \\ ${ }^{2}$ Bila Tserkva National Agrarian University, Ukraine \\ ${ }^{3}$ Zhytomyr National Agroecological University, Ukraine \\ ${ }^{4}$ Uman National University of Horticulture, Ukraine \\ *Corresponding author E-mail: shunyascience@ukr.net
}

Received 28.10.2019 Accepted 17.12.2019

\begin{abstract}
We proved that plants A. cylindrica, T. spelta, T. turgidum, T. sphaerococcum, T. vavilovii, T. persicum, T. araraticum, T. aestivum var. barbarossa, and T. aestivum var. ferrugineum, owning high drought resistance, have a stable high productive potential and quality indicators of grain (protein, gluten, dietary fiber content), that allows use them in the production of products functional purpose (bakery, confectionery, sour-dairy products, including yoghurts, and dessert cheese). Implementation mechanisms are disclosed adaptive potential plants of cultural and wild cereals by biochemical (protein content, gluten, starch in seeds, the presence of gliadin proteins (Gli-1B1, Gli-6D2, Gli-6D3, Gli-6B2), molecular-genetic markers (allele genes of drought resistance - Dreb A1, Dreb B1, Dreb $D 1$; glutenins $G(u-D 1$ ) and morphological-ontogenetic criteria. For the first time for successful address introduction cultural and wild cereal plants suggested by the criteria of mechanisms drought resistance to rank plants by potential ecological valence regarding the unfavorable hydrothermal regime. Differentiation of genotypes based on elements of plant strategies: features of their ontogeny, morphological characteristics, physiological and biochemical parameters, biochemical and molecular-genetic markers. In this connection, genotypes of cultural and wild cereal plants in conditions in situ by sensitivity on the effect of hydrothermal stress are divided into xerophytic, mesophytic and intermediate - xerophytic-mesophytic types of development. That's it ranking underlying on the principles of autecological approach, manifestation of a multi-level system of answers plant organisms at different levels of integration, as adaptive reactions. In particular, mechanisms such as: functional stability (stipulated structural and functional features of plants), morphological tolerance (the ability of plants to resist damage without reducing performance), ontogenetic evasion (stability due to features ontogenetic development), ecological plasticity of the organism and plant populations as a whole. The obtained results of the biochemical and molecular genetic markers of adaptability and quality indicators of genotypes cultural (wheat, triticale, rye) and wild cereals ( $A$. cylindrica, T. spelta, T. turgidum and others) are important in breeding and successive targeted use in the food industry are given.
\end{abstract}

Keywords: Wheat species; Rye; Amphidiploids; Adaptive properties; Alleles of genes Dreb 1; Glu-D1; Gliadin-proteins Gli; Grain quality indicators

\section{Introduction}

Global climate change, that in the last decades are observed on our planet and in particular in Ukraine, need qualitatively new approaches to the formation of adaptive potential plants of cultivated species (Moskalets et al., 2016; Qaseem et al., 2018). Significant increase in amplitude oscillations such weather factors, how the temperature, precipitation and their redistribution by seasons and months of the year, determines necessity introduction of species and creating genotypes of plants that exhibit minimal reaction to different negative changes in environmental conditions, while maintaining maximum performance (Tardieu et al., 2014; Parent et al., 2016). In the context of climate change recently of increasing importance acquires drought monitoring problem (Bita \& Gerats, 2013; Moskalets \& Rybalchenko, 2016). There are now more than 100 UNO organizations and structures are engaged problems of the drought, their estimation and forecasting (Intergovernmental Panel ..., 2014; Morgounov et al., 2014). They are observed in different climatic zones and cause huge losses. To conditions of soil drought plant organisms made a number of adaptations, detectable at different stages of their ontogeny (Thabet et al., 2018). Research and identify these adaptation are important criteria in selection valuable source material and the creation of new plant forms.

Ones of the major food and industrial crops in Ukraine and in the world are: Triticum aestivum L. (common wheat), Secale cereale L. (winter rye), and Triticale trispecies Shulind (winter triticale) (FAO ..., 2019). However, the trend of modern human nutrition are production and consumption functional products, special place among which occupy wild forms of cereal $(A$. cylindrica, $T$. spelta, $T$. turgidum and others) because in their grain have high content biologically active substances (Hussain et al., 2018; Liubych et al., 2019). With increasing genetic potential productivity new varieties reduced the level of their adaptation to certain conditions, tapering 
heterogeneity (Tardieu et al., 2014; Sallam et al., 2019). Therefore creation varieties of winter crops that are able to overcome the negative correlation between yield and adaptive potential, is a key issue today. Various kinds of stressors cause structural and metabolic changes in plants (Morgounov et al., 2014; Noman et al., 2018). Knowledge of the mechanisms that underlie their reactions to the effect of prolonged abiotic stress factors and formation stability are important in understanding the fundamentals of adaptation, developing of approaches for obtaining resistant varieties and forms of plants, especially in the present global warming and arid climate, long spring, summer and autumn drought (Sharma et al., 2017; Qaseem et al., 2018; Sukumaran et al., 2018). Topical questions are adaptation of cultural species by modern speakers environmental conditions to which the plants are able to produce protective mechanisms as marker characteristics are not only stressful, but also before and after stress periods (Hussain et al., 2018; Qaseem et al., 2018).

The aim was to investigate the biochemical, molecular-genetic markers adaptability and quality of genotypes cultural (wheat, rye and triticale) and wild cereal plants (A. cylindrica, T. spelta, T. turgidum and other), and created on their basis new hybrid combinations, important in breeding and successive targeted use in the food industry - production of products functional purpose (bakery, confectionery, sour-dairy products, including yoghurts, dessert cheese etc.).

\section{Material and Methods}

The objects of research were wild (Aegilops cylindrica Host, Triticum spelta L., Triticum turgidum L., Triticum sphaerococcum Pers., T. vavilovii (Thum.) Jacubz., T. persicum Vav. ex Zhuk., T. araraticum Jakubz., T. aestivum L. var. barbarossa (Alef.) Mansf., and T. aestivum L. var. ferrugineum (Alef.) Mansf.) and cultural cereal species, new varieties and lines of: Triticum aestivum L. (common wheat: Yuvivata 60, Zoriana Nosivska, Nosshpa 100, Ariivka, Daushka, Prydesnianska napivkarlykova, KC 1, KC 5, KC 7, KC 14, KC 16, KC 17, KC 21, L -41, L-59, and L-34-95; control - Bezosta 1; Secale cereale L. (winter rye: Hlibne, Syntetyk) and Triticale trispecies Shulind (winter triticale: Chaian, Urahan, Vivate Nosivske, Pshenychne, Slavetne, Dovhokolose nosivske, УП_1-12, Nove nosivske, Chornoostyste, i.e., from Vivate Nosivske, PS_1-12, PS_2-12, PS_3-12, PS_4-12, PS_5-12, PS_6-12, L-6-12, and AДM 11; control - AD 52 and Karluk umanskyi). The studies were performed under conditions of Forest-Steppe (Research field NSRC of Bila Tserkva NAU and Nosivska selection) and Polissia-Forest-Steppe during the 2008-2017 in the central part of Northern Right-Bank Forest-Steppe of zone periodically unstable wetting (research station of V.M. Remeslo Myronivka Institute of Wheat of NAAS of Ukraine). From 20172019 studies were conducted in the northern part of the central Forest-Steppe - Institute of Horticulture of the National Academy of Agrarian Sciences of Ukraine (the soil is dark gray podzolic, the content of easily hydrolysed nitrogen 89 , of mobile phosphorus 153 , of exchangeable potassium $111 \mathrm{mg} \mathrm{kg}^{-1}$ ).

Climate and weather conditions in Forest-Steppe are characterized by moderate continentality. The average air temperature is $6.9^{\circ} \mathrm{C}$ with significant fluctuations by months and average annual rainfall of $538 \mathrm{~mm}$, which during the growing season unevenly distributed: in summer it is much more than in the spring and fall. Probability years with rainfall less than $350 \mathrm{~mm}-$ about $35 \%$. In the studies used conventional technology for the region grain crops winter crops. Soil - black humus earth general, deep, medium humic and clayloam soil, with humus content - 3.5\% low-duty hydrolizable nitrogen (for Kornfild) - 140 mobile phosphorus and exchangeable potassium (by Chirikov) - respectively 120 and $90 \mathrm{mg} \mathrm{kg}^{-1}$ soil. The soil is characterized by average nitrifiable ability - 20-35 mg 100 $\mathrm{kg}^{-1}$ totally dry soil and average the gross providing compounds $\mathrm{P}_{2} \mathrm{O}_{5}$ and $\mathrm{K}_{2} \mathrm{O}$. Sowing was carried out in the optimal for zone dates: 15-25 September, string method of seeding norm of similar 5.0 million seeds/ha.

Years of research have varied by hydrothermal regime: 2011-2013, 2015-2019 marked deficits rainfall and increased temperatures above average long-term norms in phase outlet pipes and phase of formation spike compared with favorable enough wet spring period (2008-2010, 2014-2019), which gave opportunity to comprehensively evaluate the adaptability the studied plant genotypes to climate in Forest-Steppe and Polissia- Forest-Steppe ecotopes and the ability to realize theirs biological potential.

The identification of low-gliadin proteins were performed by electrophoresis polyacrylamide gel (Popierielia, 1989; Osterman, 2002) in collaboration with the Plant Production Institute nd. a. V.Ya. Yuryev of NAAS of Ukraine using the catalog and nomenclature Payne (Payne, Lawrence, 1983). Identification alleles genes drought, genes G/u-D1, conducted in collaboration with the Institute of Cell Biology and Genetic Engineering NAS of Ukraine and using uniplex and multiplex PCR. The study used gene primers Dreb 1: P21F/P21R, R25F/PR, P22F/PR, R18F/R18R, R20F/P20R according to Wei et al. (2009), gene G/u-D1: UMN25F/UMN25R to Liu et al. (2008). Morphological parameters of plants (leaf, bush, spike, grain) and stages of ontogeny calculated by Avdieiev (2015). Biometric parameters elements of the plants structure included: height of plants, length of the main spike, number of spikelets in the main spike, the number of grains in the main spike, the mass of grain from it, mass of 1000 grains and harvest from the area $10 \mathrm{~m}^{2}$. The content of protein and gluten determined on appliance Inframatic 8600, dietary fiber (cellulose) - on analyzer FIWE-3 (Rogozhin, Rogozhina, 2013). The differences between the values in the control and experimental groups were determined using the ANOVA, where the differences were considered significant at $P<0.05$ (with Bonferroni correction). The results were defined as means \pm standard error ( $\mathrm{x}$ $\pm S E$ ). When calculating the standard error of the mean (SDX) using the standard deviation, taking into account Bessel's correction, because the calculations took into account not big sample value $(n \leq 12)$.

\section{Results and Discussion}

Reactions of plants to changing environmental conditions necessarily related to synthesis of stress proteins. In the composition of proteins includes valuable structural high molecular weight and low molecular weight subunits, significant place among which occupy spare proteins - gliadins and gluteins, as molecular and biochemical markers adaptability and quality of plants. The composition of wheat gliadin controlled by six major loci of genes (Figure 1 ).

As a result of holding electrophoresis (Figures 2-4) gliadin complexes of spare proteins of the endosperm, found that in the genotypes of some cultural plants (Daushka, Nosshpa 100, Prydesnianska napivkarlykova, KC 16, KC 21, KC 22, and Pshenychne) and wild samples have presence of the block $1 \mathrm{~A} \mathrm{10}$, which indicates about good quality of gluten and theirs belonging to strong wheat. Some samples (Zoriana Nosivska, KC 14, Nosshpa 100, Yuvivata 60, and KC 5), as rye (varieties: Hlibne, Syntetyk) and triticale (Pshenychne, Chaian, and Slavetne) available the block of gliadins 1 B 3 - the so-called 'rye translocation', indicating, on the one hand, the possible poor. 


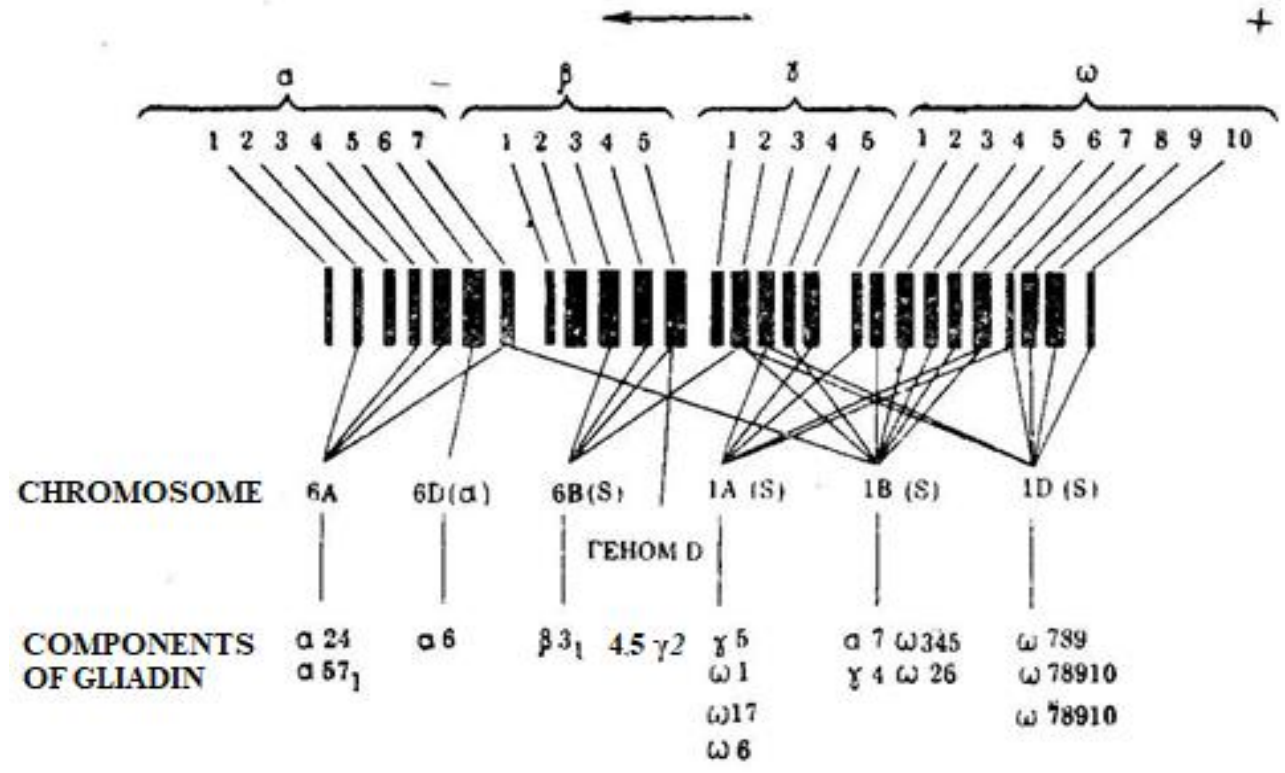

Figure 1. Genetic control of gliadin.

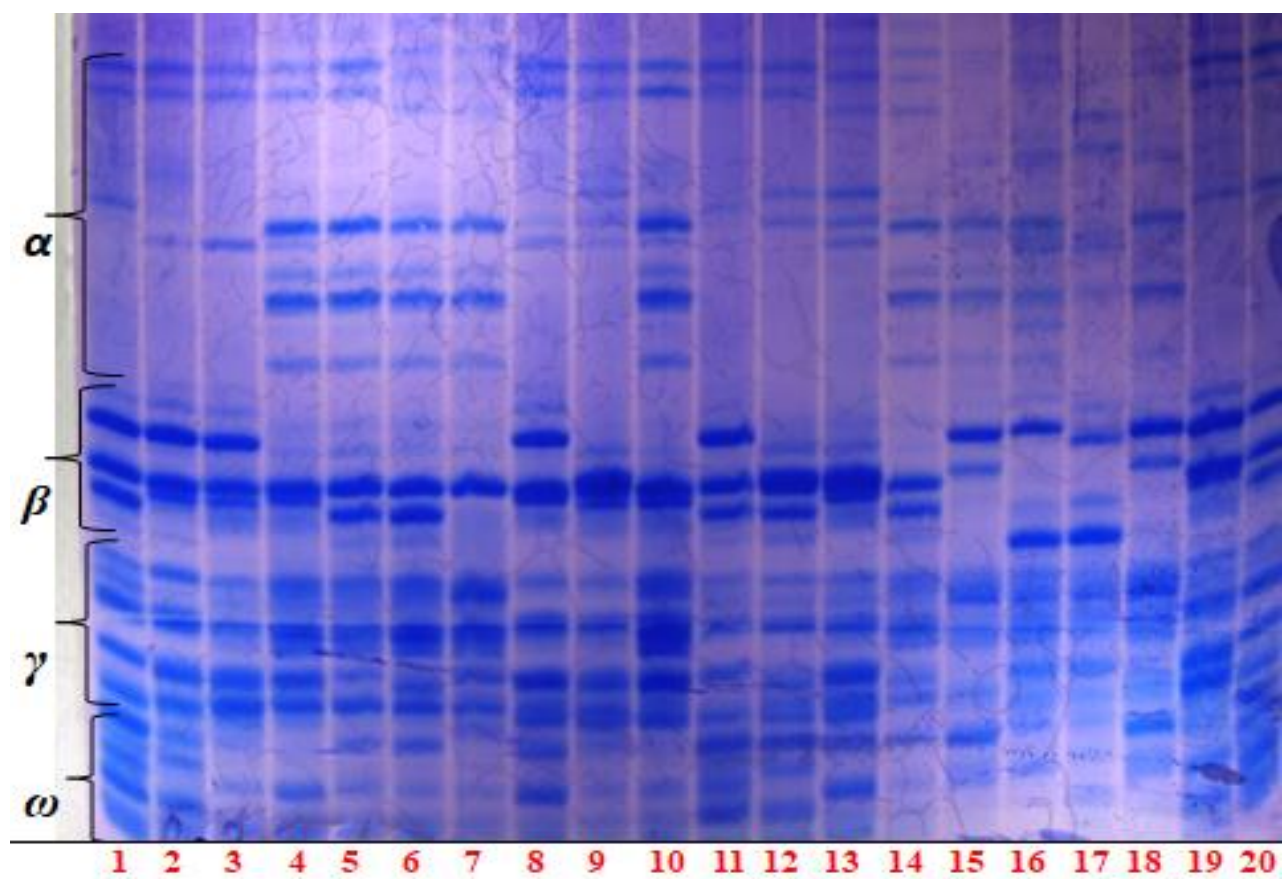

Figure 2. Electrophoretic spectra of spare gliadin controlled by Gli genes in T. aestivum and T. trispecies. 1, 11, 20-Bezosta 1 (control); 2-Daushka; 3-Prydesnianska napivkarlykova; 4-Zoriana Nosivska; 5-KC 14; 6, 14- Nosshpa 100; 7-Yuvivata 60; 8 - KC 16; 9- KC 7; 10-KC 5; 12-KC 17; 13-KC 22; 15, 18-Pshenychne; 16-Chaian; 17-Slavetne; 19 - KC 21.

Quality of gluten, however, high drought resistance and productivity. Would like to note among the samples the uniqueness of the wheat line KC 16, that having alleles in loci 1 B, in particular, 1 B 12, responsible for the poor quality of flour, has high adaptation potential, including drought resistance. Genotypes of lines KC-7, KC-17, KC 21, KC 22, and Nosshpa 100 have in chromosomes $1 \mathrm{~A}$, $1 \mathrm{~B}$, and 1D blocks of high (1 A 10, 1 B 1, 1 D 2, and 1 D 4) and low quality (1 B 12, 1 B 14), that does not give opportunities, by alleles of these loci, make an objective assessment about their suitability in production of high quality bakery products. This is evidence, that biochemical markers necessarily should be confirmed or denied presence molecular genetic markers, biochemical parameters. In connection with global climate change, uneven distribution of precipitation, increasing the number and duration of droughts in Europe and Ukraine, is gaining in importance the introduction of high-performance genotypes with high adaptive potential as well as bringing in drought resistant ones wild cereals to the breeding process. Therefore, the next stage of our research was to determine the drought resistance of plant samples by molecular genetic markers of drought resistance, in particular by the presence of alleles of genes Dreb 1 (dehydration responsive element binding factors 1 ). Alleles of these genes are located in three $-3 B, 3 D i 3 A$ chromosomes (Wei et al., 2009; Liu Meng et al., 2018). According to electrophoregrams installed, that in the samples tested T. aestivum, T. aestivum var. barbarossa and $A$. cylindrica obtained expected amplicons, the size of which 717, 789, 596, 1113, 1193 p.n. The exceptions are the genotypes of those samples (Daushka, KC 1, KC 17), in which the amplicons 1113 p.n. (in 3D) and 1193 p.n. (in 3A chromosome) were not detected (Figures 3-5). 


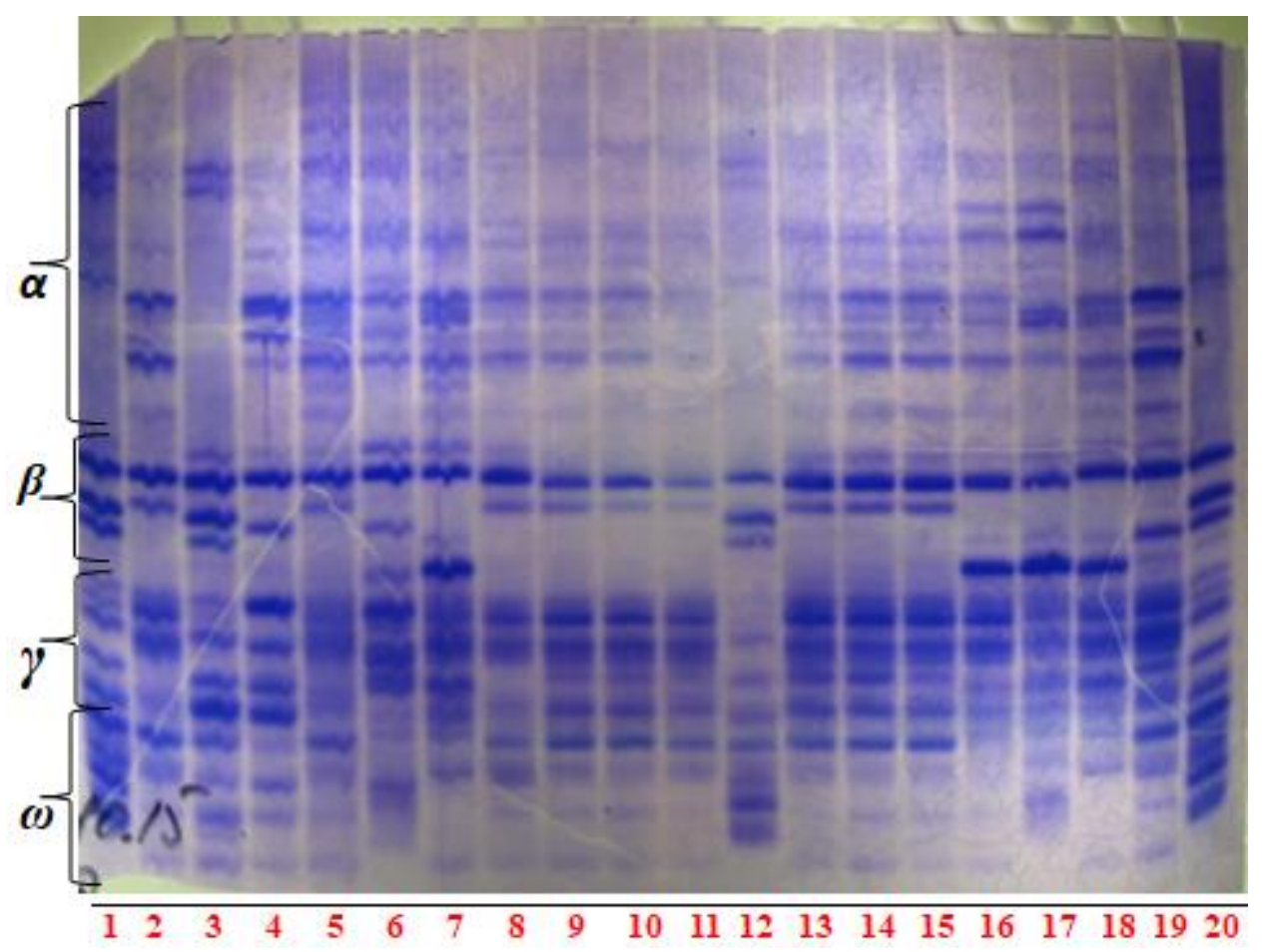

Figure 3. Electrophoretic spectra of spare gliadin controlled by Gli genes in T. aestivum and T. trispecies: $1,12,20-$ Bezosta 1 (control); 2 - Chaian; 3 - Prydesnianska napivkarlykova; 4 - Dovhokolose nosivske; 5 - УП_1-12; 6 - Nove nosivske; 7 Chornoostyste; 8, 18 - i.s. from Vivate Nosivske; 9- PS_1-12; $10-$ PS_2-12; 11 - PS_3-12; 13-PS_4-12; 14-PS_5-12; 15-PS_612; 16- L-6-12; 17-АД 52; 19- Karluk umanskyi.

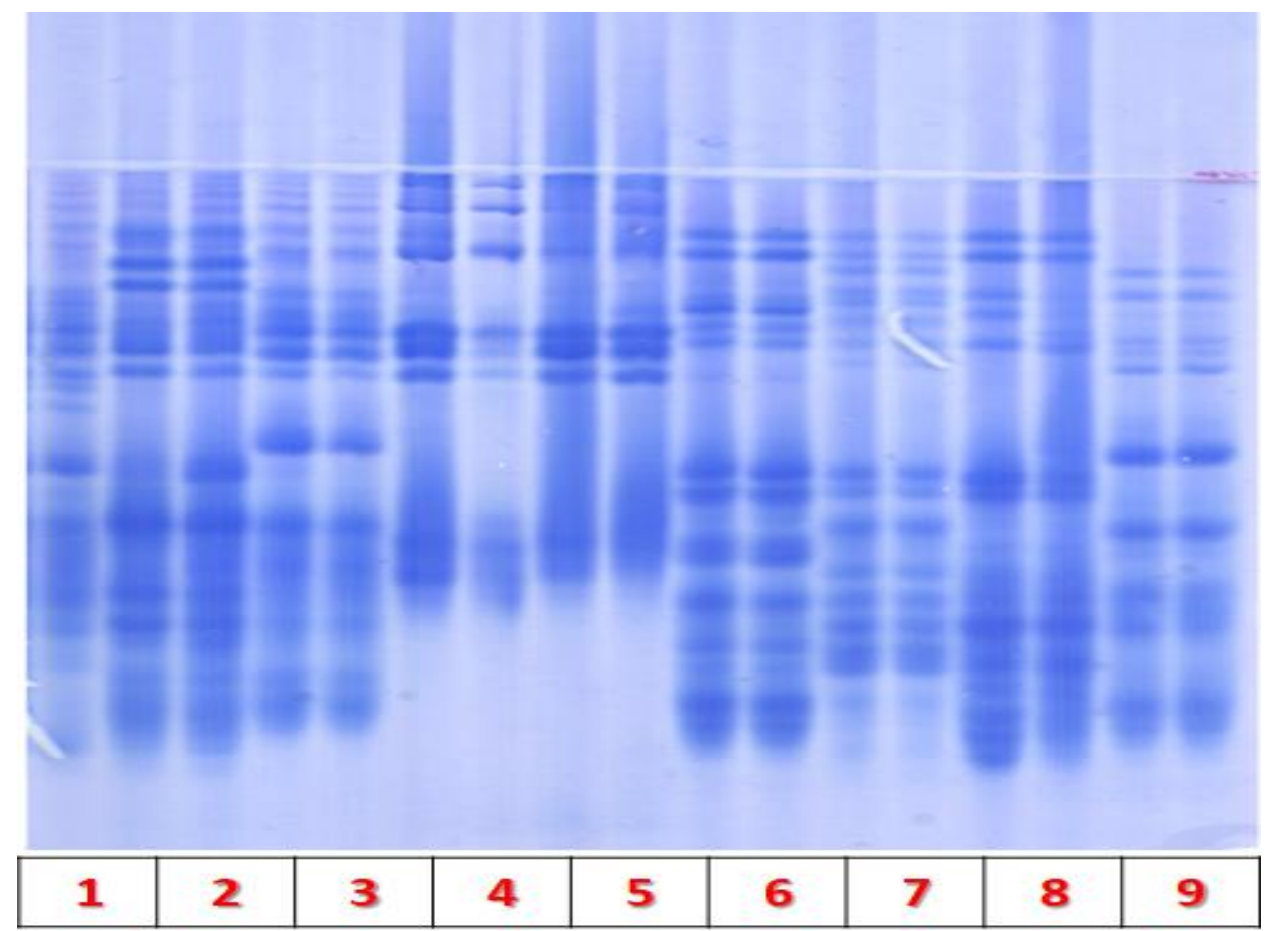

Figure 4. Electrophoretic spectra of spare gliadin controlled by Gli genes in wild and cultural cereal species ( T. aestivum, T. trispecies, S. cereale): 1 - Urahan; 2 - Slavetne; 3-Chaian; 4-Syntetyk; 5 - Hlibne; 6- T. spelta; 7 - wheat-pyrium amphidiploid; 8 ADM 11; 9- T. Turgidum. 


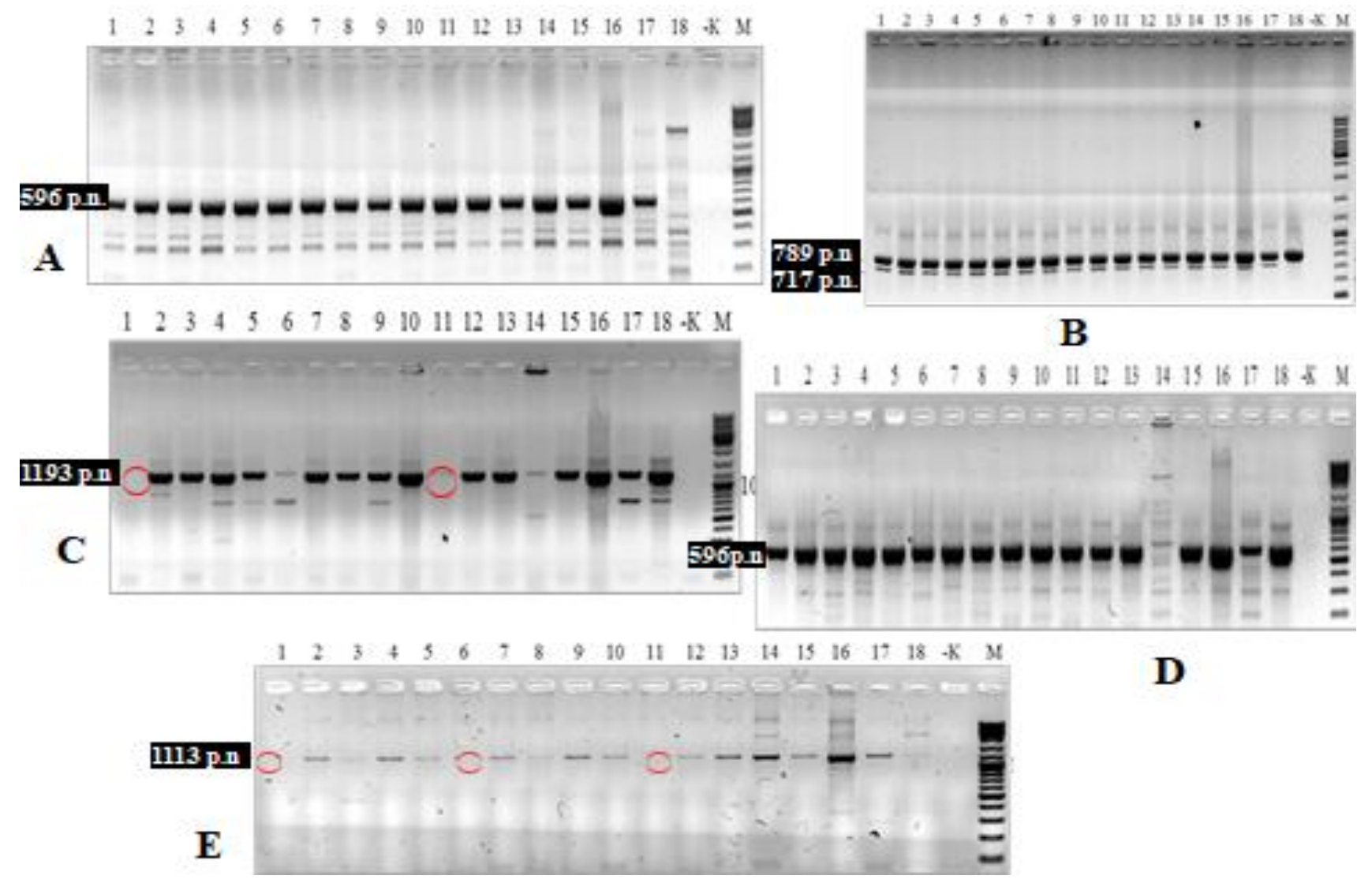

Figure 5. Electrophoregram amplification products of Dreb 1gene in plant genotypes of cultural and wild cereals: 1 - KC 1 ; 2 Yuvivata 60; 3 - KC 5; 4 - L 41/95; 5 - KC 14; 6 - KC 17; 7 - KC 16-04; 8 - L 59-95; 9 - Zoriana Nosivska; 10 - KC 21; 11 Daushka; 12 - KC 7-04; 13 - L 3-95; 14 - T. aestivum var. barbarossa, 15, 16, 17-control plants; $18-A$. cylindrica; $-K-$ negative control (without DNA); $M$ - control marker; $A, B-3 \mathrm{~A}$ chromosome; $C-3 \mathrm{~B}$ chromosome; $D, E-3 \mathrm{D}$ chromosome.

In plants of the variety Yuvivata 60 and the line KC 21 according to electrophoretic analysis the spectra of the amplification products were identified high glutenin subunits gene $G / u-D 1$, in particular, the allele G/u-D1 " $5+10$ ", which were introduced two components size 397 and 281 p.n. and allele Glu-D1 "2 + 12" - amplicon size 415 and 299 p. n., respectively (Figure 6).

Our results are confirmed by the data A. I. Ghazy (Ghazy et al., 2012) and V. M. Tishchienko (Tishchienko et al., 2013), which show that plants containing subunits " $2+12$ " capable of forming high quality grain in conditions of soil and atmospheric drought, due to the higher adaptability, compared to plants that have subunits " $5+10$ ". Most plants of cereal crops are xerophytic type of development

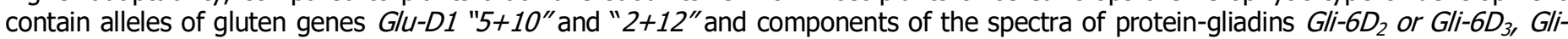
$6 B_{2}$, the expression of which are reflected in substantially $(p<0.05)$ higher protein content in the seed $(\geq 13.5 \%)$.

The study of morphological parameters of genotypes cultural and wild cereal plants made it possible to detection of certain characteristics xeromorphic, and their subsequent cultivation enabled to compare them with other criteria and identify correlations. Feature distribution of precipitation in the central Forest-Steppe and Polissia- Forest-Steppe of Ukraine is characterized by that deficit of the autumn soil moisture often makes it impossible get a full staircase so the study of drought in the phase of sprouting grains is not only theoretical but also practical. Germination and growth of seeds in osmotic solutions of sucrose simulates the deficit of moisture and makes it possible to establish the overall level of physiological and biochemical processes in the germinated seeds under stress, which determines the resistance of adult plants.

The research results of new genotypes drought resistance cultural and wild cereal plants on the juvenile stage of development germination sprouts in sucrose solutions with different osmotic pressure indicate a high level of samples polymorphism. Its were established that the solution of the osmotic pressure of 14 atm sprouted up in average $90-82 \%, 16$ atm - 75\%, 18 atm - 56-50\%, $20 \mathrm{~atm}-26-21 \%, 22 \mathrm{~atm}-12 \%, 24 \mathrm{~atm}-5 \%$ seeds. The high drought tolerance in this phase on osmotic pressure of $14-18$ atm sucrose solutions have seeds of: A. cylindrica, T. spelta, T. turgidum, T. sphaerococcum, T. vavilovii, T. persicum, T. araraticum, T. aestivum var. Barbarossa, and T. aestivum var. ferrugineum and also varieties, lines of winter triticale and wheat: Chaian, Zoriana Nosivska, KC 16, KC 21, and KC 5. The lowest ability to grow with sucrose solutions have: Daushka, KC 1, KC 17, and Ariivka and all others formed the group are "medium" and "low" resistance. For coefficient of variation materiality on precipitation vegetation periods 2009, 2010, 2011, 2012, 2013 and 2014-2019 were arid (coefficient of variation materiality < 1); the coefficient of variation materiality of the temperature regime - close to the average long-term exponent $( \pm 0.2-1.3)$. However coefficient of variation materiality for hydrothermal coefficient (index) (HTI) during the research approached the value of the index in conditions close to extreme. The most extreme months of atypical weather conditions were in May 2010-2014, 2017 (-4.6) July 2010, $2012-2018$ ($2.25--2.48)$, that in all the years research May - the period of active plant growth and development - characterized by the most extreme weather conditions, which significantly delayed accumulation intensity of dry vegetative mass. Generalized analysis of of meteorological conditions suggests that deviation of a number of parameters, including temperature, an amount of precipitation with medium perennial away from the critical values, except for some months of growth plants in the year. 


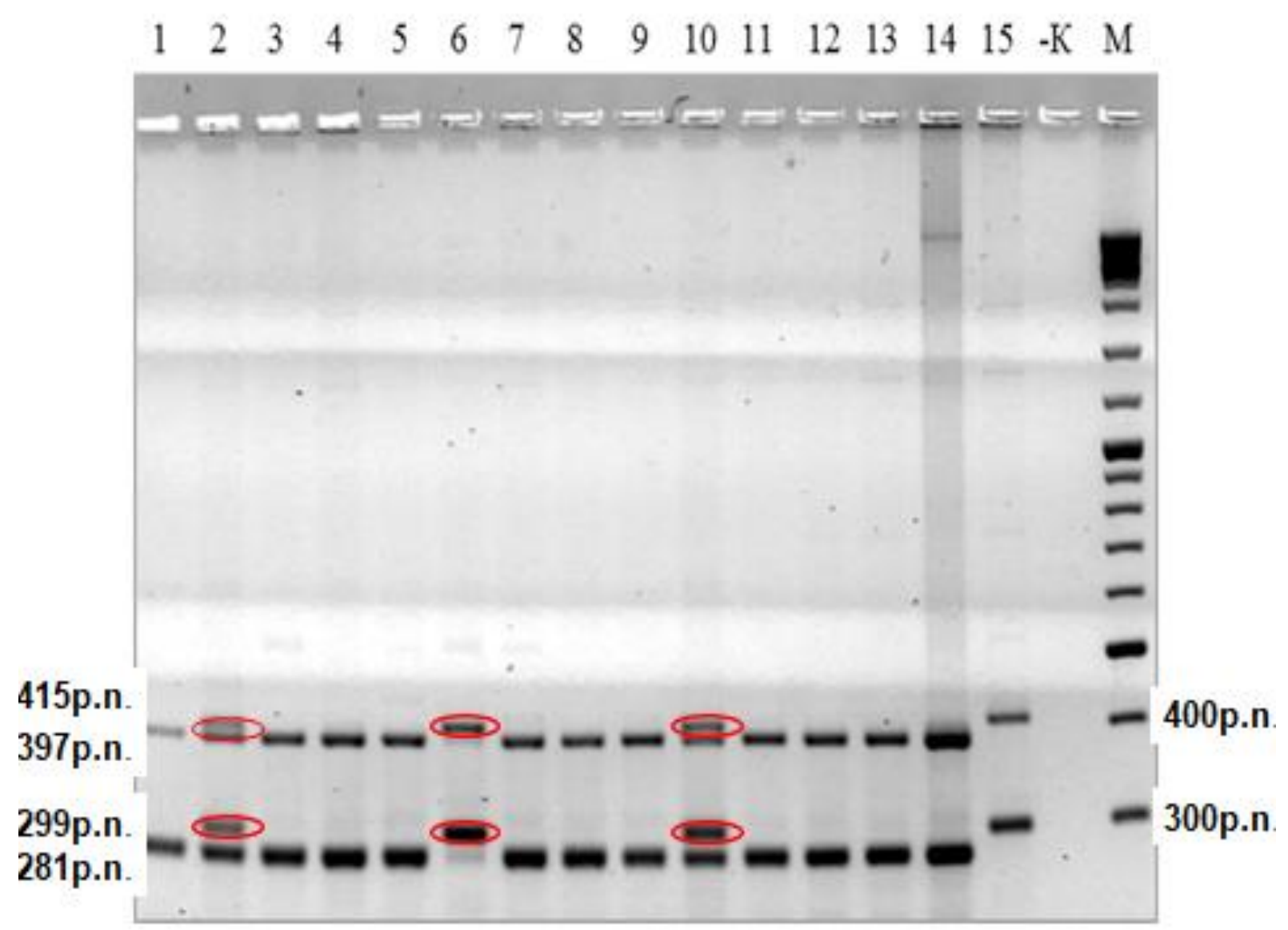

Figure 6. Electrophoregram of Glu-D1 gene amplification products of plants genotypes of cultural and wild cereal species: $1-\mathrm{KC} 1 ; 2$ - Yuvivata 60; 3 - KC 5; 4-L 41; 5 - KC 14; 6-KC 17; 7-KC 16; 8 - 59; 9 - Zoriana Nosivska; 10 - KC 21; 11 - Daushka; 12 KC 7; 13 - L 34-95; 14 - Dvorianka; 15 - Trizo; 16 - Kuialnyk; $17-$ Smuhlianka; $18-A$. cylindrica; $-K$ - negative control (without DNA); $M-$ molecular weight marker GeneRuler ${ }^{\mathrm{TM}}$ DNA Ladder Mix

Given the fact that drought-resistant forms have usually low crop yield important for them to have stable performance under different hydrothermal conditions during 2008-2019 (Zoriana Nosivska and Nosshpa 100), which characterized by glasslike well-filled grain (60$70 \%)$ and test weight (760-815 g L$)^{-1}$, which are important features of productivity and drought resistance. Morpho-physiological drought resistance criteria are: a high index of leaf (> 14.2), glossy coating, long-term assimilation ability flag leaf during milky-wax and wax ripeness, the presence of awns.

The success of the introduction cultural cereals, that have food significance, is high quality grain parameters, including protein content, dietary fiber and gluten. Features of accumulation of these substances under hydrothermal stress conditions can be considered as mechanisms of the adaptive reactions of plants. Ecological testing of plants in the Forest-Steppe conditions allowed to detect substantially $(P<0.05)$ higher $0.4-1.12 \%$ protein content, and $0.9-4.45 \%$ gluten in the seeds of most of the studied plants (Table 1$)$, why higher values contribute totalphotosynthetically active radiation, sums of active and effective temperatures, compared to habitat Polissia-Forest-Steppe.

High protein content of grain conditioned not just the growing conditions and the results of the interaction genotype with the environment, but also genetically - the presence of molecular and biochemical markers (alleles of genes $G / u-D 1_{5+10}$, $G / u-D 1_{2+12}$ Gli 1D4, Gli 1D5, Gli 1D7, Gli 1D10, and Gli 6A), which control synthesis high molecular weight spare glutenin and gliadin, displaying in parallel highly adaptive drought-resistant potential. Between gluten content, protein in seeds and indicators of relative drought resistance - the ability of seed germination on osmotic solutions of 14 and 16 atm. found positive weak $(r=0.21-0.32)$ and medium positive correlation interdependence $(r=0.67-0.70)$. Correlation between indicators of high drought resistance and total protein in wheat, rye and triticale amounted $0.64-0.75$. The relationship of these adaptive properties with a total protein content in grain-rich explains the influence of stress marker polymers. Adverse abiotic factors during the growing season helped to highlight the highly adapted and stable biotypes on indicators dry matter accumulation.

One of the universal reserve carbohydrates of plants, which plays an important role in their metabolism, there is starch. Its synthesis and decay directly related to Calvin cycle during photosynthesis and the process of dark breathing. A group of polysaccharides, heterogeneous in biochemical composition, represent dietary fiber - as a mixture of cellulose, hemicellulose, pectin, protopectin, resistant types of starch, chitin, lignin and kutyn. Resistance of plants to drought closely related to seed productivity, which largely determined by morphological parameters and genetic potential. Indicators of biochemical composition of grain are shown in Table 1. As can be seen from table data, samples of cultural and wild wheat species, rye and triticale are different by protein content, gluten, cellulose as dietary fiber, and also the presence of antioxidant substances - flavonoids and anthocyanins. 
Lowest protein content observed in rye (variety Syntetyk $-10.5 \pm 0.2 \%$ ), and the highest content $-19.8 \% \pm 0.6$ in the variety LPP 3118 ( T. spelta) and in the variety Sharada ( T. sphaerococcum) $-21.5 \% \pm 0.5$, respectively. By these characteristics are distinguished the genotypes of A. cylindrica, T. spelta, T. turgidum, T. sphaerococcum, T. vavilovii, T. persicum, T. araraticum, T. aestivum var. barbarossa, and T. aestivum var. ferrugineum and varieties, lines of winter triticale and winter wheat. Hybrids obtained on their basis also have high biological value, in particular, protein content $(\geq 14.8 \%)$, gluten $(\geq 34.2-34.4 \%)$ and dietary fiber ( $2.6 \%$ and higher), indicating that the feasibility involvement to the breeding process wild forms of wheat. Adding flour and bran of the species under study during the manufacture of food products will contribute increasing the raw material base for the production of functional wellness products, expanding the range of bakery, confectionery (biscuits, desserts) lactic acid products (cheese, yogurt), giving them functional properties and improving organo-leptical indicators. It should be noted apart from the nutritional value of such wheat high adaptive potential allowing in the face of global climate change grow them on an industrial scale, providing a human diet the required amount of biologically valuable products.

Years of research differed by hydrothermal regime (especially in 2008, 2011-2013, 2017-2018), which was noted in more than 50$80 \%$ rainfall deficit and raising temperatures above the annual average (on $1.8-2.3 \mathrm{C}^{\circ}$ ) during critical phenophases growth and development of plants: bushing-outlet pipes, spike-flowering, milky and waxy ripeness, compared to favorable ones wet enough spring periods (2009-2010, 2014). This contrast weather and climatic conditions allowed a comprehensive assessment adaptive potential of plants cereal species by the ability to realize their biopotential. Moisture deficiency (noted by GTI < 1) induces excessive energy consumption and a decrease in growth processes, that confirm the data increase of dry biomass in less drought-resistant plants (KC 1 , KC 17, Ariivka, Daushka, Prydesnianska napivkarlykova) - which we refer to as plants of mesophytic type of development. On the contrary, under the same conditions genotypes of xerophytic (A. cylindrica, T. spelta, T. turgidum, T. sphaerococcum, T. vavilovii, T. persicum, T. araraticum, T. aestivum var. barbarossa, and T. aestivum var. ferrugineum and varieties, lines of winter triticale and wheat: Chaian, Vivate Nosivske, Zoriana Nosivska, KC 16, KC 21, KC 5, Zoriana Nosivska, Nosshpa 100, KC 16, KC 21, and PS-2-12) and xerophytic-mesophytic types of development (varieties, lines of winter wheat and winter rye: Hlibne, Syntetyk, Prydesnianska napivkarlykova, Yuvivata 60) into the critical phenophases of ontogeny not marked induction excessive energy consumption and inhibition of growth processes, which is reflected in substantially $(P<0.05)$ higher by $18-26 \%$ weight gain of a dry substance $(6.2-8.4$ $\mathrm{g}$ in phase bushing-outlet pipes, in phase spike-flowering - 13.7-14.3 g; and in phase milky ripeness - 16.4-17.8 $\mathrm{g} / 10 \mathrm{plants,}$ respectively). By optimal moisture supply (GTI > 1.5) plants of mesophytic type of development accumulate dry matter at the level of plants xerophytic type (in phase spike-flowering $13.1-16.3 \mathrm{~g}$ and in phase milky ripeness - 22.1-26.6 g/10 plants, respectively). In all the studied plants on the shortage of moisture the triggered mechanism functional stability, manifested in variability morphological parameters (fullness grain, mass 1000 grains, test weight of grain, its surface). Plants with resistance to hydrothermal stress characterized by pubescence of the spike; a broad hardened the spiky scales, that completely cover the grain, fit snugly to the stem of the leaf vagina.

The manifestations of the mechanism of morphological tolerance are: plant height; hairiness of leaves, stems; presence of wax coating; shape of bush; the density of the spikes; glossy surface and bluish color of leaves, stems; the density of the flower scales adhering to the grains and others. Mechanisms of ontogenetic evasion - as factors for avoiding drought are mismatch critical periods of ontogeny of plants with periods of drought, the duration of the phases, including flowering, pour grain, maturation, latent and vegetative periods, soon ripeness. And also, the formation of a smaller area of leaf surface $\left(\leq 20 \mathrm{~cm}^{2}\right)$, on the one hand, however, more intensive synthesis and the accumulation of plastic substances in the generative parts (spike), as evidenced by the their relatively high productivity (>8.9 g/plant). Plant research at different levels of their integration made possible to find out what structural and functional organization plant organisms, their populations and grouping under the influence of the environment factors causes the formation of a multilevel system of adaptive reactions, manifestations of which are marker features adaptive properties of plants, are predetermined to adaptive mechanisms. Analyzing and finding correlation interdependencies between morphological features, their parameters are molecular genetic and biochemical markers and potential (relative) drought resistance gave grounds to rank the genotypes of cereal plants for potential ecological valence regarding the hydrothermal regime by the criteria of drought resistance mechanisms into three types of development: mesophytic, xerophytic and intermediate - xerophytic-mesophytic.

The study of plant genotypes cultural and wild species of cereals by morphological, ontogenetic, biochemical, molecular-genetic markers and features in Polissia-Forest-Steppe and Forest-Steppe of Ukraine made it possible to detect, that plants are capable of producing multilevel system of adaptive reactions to conditions of unfavorable hydrothermal regime. These reactions in plants are based on the principles of strategy elements such adaptive mechanisms as mechanism of functional stability (stipulated structural and functional features of plants), morphological tolerance (the ability of plants to resist damage without reducing performance), ontogenetic evasion (stability due to features ontogenetic development), ecological plasticity of the organism and plant populations as a whole.

\section{Conclusion}

For the first time on the example of plant genotypes of cultivars and wild cereal species by the criteria of drought resistance mechanisms by potential ecological valence on action unfavorable hydrothermal regime shown the ranking on xerophytic, xerophyticmesophytic and mesophytic types of development. Such is the grouping of plants of cereal species convenient and efficient with their ecological and biological characteristics for effective carrying out targeted address introduction valuable plant forms. Finding out biochemical, molecular genetic markers of adaptability and quality indicators genotypes of cultural (wheat, triticale) and wild cereals (A. cylindrica, T. spelta, T. turgidum, T. sphaerococcum, T. vavilovii, T. persicum, T. araraticum, T. aestivum var. barbarossa, and T. aestivum var. ferrugineum) are important in breeding and further targeted use in the food industry. It is shown that plants owning high drought resistance, have a stable high productive potential and quality indicators of grain, that allows use them in the production of products functional purpose: bakery, confectionery (biscuits, desserts), and lactic acid products (cheese, yogurt). 
Table 1. Biochemical composition of cultural and wild cereals and their hybrids as a valuable raw material in the production of functional products, the average 2016-2019 (n=3), Forest-Steppe.

\section{Content, \%}

Specie, variation/Variety, Line, Hybrid Combination
Cellulose

\section{The Suitability of Grain for the Production of Functione Products}

Flour Biscuit
Cereal Flakes

\section{T. aestivum var. erythrospermum}

Smuhlianka (st)

Chornobrova

Yuvivata 60

Zoriana Nosivska

L 41-95

L 59-95

KC 22

KC 21

Ariivka

KC 17

KC 7

\% Chornobrova x ớKC 22

\&Chornobrova $x$ ơl 59-95

¡Chornobrova $x$ ớ 41-95

T. a.var. ferrugineum $\mathrm{x}$ ơ KC 7

९ T. a.var. ferrugineum $\mathrm{x}$ ơ KC 14

○T. a. var. barbarossa $\mathrm{x}$ ơ KC 14

○ T. a. var. barbarossa $\mathrm{x}$ ơKC 7

९KC 17 x ơ T. a. var. barbarossa

\section{T. spelta}

१ T. spelta $x$ ớL41-95

LPP 3118

$\begin{array}{cc}- & 14.4 \pm 0.2 \\ - & 13.5 \pm 0.3 \\ 2.8 \pm 0.2 & 13.9 \pm 0.4 \\ 2.6 \pm 0.1 & 12.6 \pm 0.7 \\ 3.0 \pm 0.1 & 12.0 \pm 0.2 \\ 2.6 \pm 0.2 & 13.2 \pm 0.5 \\ 2.4 \pm 0.1 & 12.5 \pm 0.2 \\ 2.7 \pm 0.1 & 13.0 \pm 0.1 \\ 2.5 \pm 0.1 & 14.6 \pm 0.2 \\ 2.9 \pm 0.1 & 12.8 \pm 0.2 \\ 2.5 \pm 0.1 & 13.2 \pm 0.4 \\ 2.9 \pm 0.2 & 14.3 \pm 0.6 \\ 2.8 \pm 0.1 & 13.6 \pm 0.5 \\ 3.2 \pm 0.1 & 13.3 \pm 0.2\end{array}$

T. aestivum var. ferrugineum
Anthocyanins

$30 \pm 0.8$
-
$29.5 \pm 0.7$
$29.4 \pm 0.4$
$30.7 \pm 0.8$
$32.4 \pm 0.6$
$33.5 \pm 0.5$
$33.6 \pm 0.9$
$35.5 \pm 0.6$
$34.0 \pm 0.9$
$31.5 \pm 0.7$
$26.4 \pm 0.5$
$28.7 \pm 0.8$
$24.0 \pm 0.6$

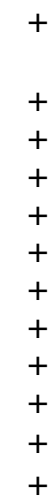

$+$

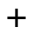

$+$

$+$

$+$

$+$

$+$

$+$

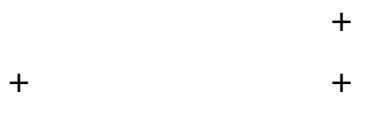

\section{$2.9 \pm 0.1$ \\ $2.8 \pm 0.2$ \\ $14.3 \pm 0.3$ \\ $34.5 \pm 0.7$ \\ T. aestivum var. barbarossa}

$\begin{array}{lll}2.5 \pm 0.1 & 14.5 \pm 0.2 & 30.8 \pm 0.8 \\ 2.3 \pm 0.1 & 13.5 \pm 0.4 & 32.2 \pm 0.9 \\ 2.6 \pm 0.2 & 14.5 \pm 0.2 & 29.7 \pm 0.7\end{array}$

T. spelta

$4.3 \pm 0.1$

$15.5 \pm 0.1$

$41.0 \pm 0.5$

$3.4 \pm 0.1$

$14.8 \pm 0.5$

$34.2 \pm 0.9$

$3.8 \pm 0.1$

$19.8 \pm 0.6$

$39.1 \pm 0.3$

\section{T. sphaerococcum}

$\begin{array}{lll}- & 19.5 \pm 0.4 & 33.5 \pm 0.4 \\ - & 21.5 \pm 0.5 & 38.6 \pm 0.5 \\ - & 17.2 \pm 0.3 & 32.6 \pm 0.3 \\ - & 16.1 \pm 0.4 & 30.0 \pm 0.2 \\ - & 14.7 \pm 0.2 & 32.3 \pm 0.8\end{array}$

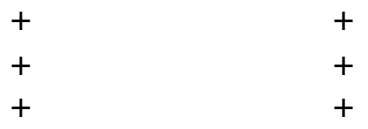

$\begin{array}{rrr} & + & + \\ + & + & + \\ + & +\end{array}$

Yeremieievna

Sharada

Praskovia

¡Zoriana Nosivska x ơPraskovia

@Praskovia $x$ o'KC 22

\section{References}

Avdeev, V. (2015). Modern methods of biometrics in the study of plants. Orenburg: Publishing Center OSAU, 130 (in Russian).

Bita, C., Gerats, T. (2013). Plant tolerance to high temperature in a changing environment: scientific fundamentals and production of heat stress-tolerant crops. Frontiers in Plant Science, 4, 273. doi: 10.3389/fpls.2013.00273.

FAO World Food and Agriculture Statistical Yearbook. (2019). Available from: http://www.fao.org/3/i3107e/i3107e.pdf. Accessed on 02.10.2019.

Ghazi, A.I., Zanouny, A.I., Moustafa, K.A., AI-Doss, A.A. (2012). Molecular screening of high molecular weight glutenin genes in spring bread wheat genotypes in Saudi Arabia. Journal of Food, Agriculture \& Environment, 10, 157-161.

Hussain, H.A., Hussain, S., Khaliq, A., Ashraf, U., Anjum, S.A., Men, S., Wang, L. (2018). Chilling and Drought Stresses in Crop Plants: Implications, Cross Talk, and Potential Management Opportunities. Frontiers in Plant Science, 9. doi: 10.3389/fpls.2018.00393

Intergovernmental Panel on Climate Change, 2014. (2014). Climate Change 2014: Impacts, Adaptation, and Vulnerability (eds Field C. B. et al.) [serial online]. Cambridge University Press. doi:10.1017/CBO9781107415324. Accessed on 20.11.2019.

Liubych, V., Novikov, V., Polianetska, I., Usyk, S., Petrenko, V., Khomenko, S., Zorunko, V., Balabak, O., Moskalets, V., Moskalets, T. (2019). Improvement of the process of hydrothermal treatment and peeling of spelt wheat grain during cereal production. EasternEuropean Journal of Enterprise Technologies, 3(11), 40-51. DOI: 10.15587/1729-4061.2019.170297 
Liu, S. X., Chao, S. M., Anderson, J. A. (2008). New DNA markers for high molecular weight glutenin subunits in wheat. Theoretical and Applied Genetics, 118, 177-183. doi: 10.1007/s00122-008-0886-0

Liu, Meng, Wang, Zeng, Xiao, Hong-mei. (2018). Characterization of TaDREB1 in wheat genotypes with different seed germination under osmotic stress. Hereditas, 155, 26. doi: 10.1186/s41065-018-0064-6

Moskalets, T.Z., Rybalchenko, V.K. (2016). Conceptual model of management the vital state plant ecomorphs by the criteria of mechanisms adaptability. Visnyk of Dnipropetrovsk University. Biology, ecology. 24(1), 211-221 (in Ukrainian). doi:10.15421/011626

Moskalets, T.Z., Vasylkivskyi, S.P., Morgun, B.V., Moskalets, V.I., Moskalets, V.V., Rybalchenko, V.K. (2016). New genotypes and technological indicators of winter triticale. Biotechnologia Acta, 9(1), 79-86 (in Ukrainian). doi: 10.15407/biotech9.01.079

Morgounov, A.I., Gummadov, N., Belen, S., Kaya, Y., Keser, M., Mursalova, J. (2014). Association of digital photo parameters and NDVI with winter wheat grain yield in variable environments Turk. Journal of Agriculture and Food Research, 38, 624-632. DOI: 10.3906/tar-1312-90

Mykhailyk, S. Yu., Antonyuk, M. Z., Ternovska, T. K. (2014). Possible molecular mechanisms of variability in gliadin genes in the wheat introgressive lines. Journal Factors in Experimental Evolution of Organisms, 14, 62-66. (In Ukrainian).

Noman, A., Ali Q., Naseem, J., Javed, M.T., Kanwal, H., Islam, W., Aqeel, M., Khalid, N., Zafar, S., Tayyeb, M., et al. (2018). Sugar beet extract acts as a natural bio-stimulant for physio-biochemical attributes in water stressed wheat (Triticum aestivum L.). Acta Physiologiae Plantarum, 40, 110. doi: 10.1007/s11738-018-2681-0

Osterman, L. A. (2002). Methods of study of proteins and nucleic acids. Moskva: MTsNMO, 248 (in Russian).

Parent, B., Vile, D., Violle, C., Tardieu, F. (2016). Towards parsimonious ecophysiological models that bridge ecology and agronomy. New Phytologist, 25. doi: 10.1111/nph.13811

Payne, P. I., Lawrence, G. J. (1983). Catalologue of alleles for the complex gene loci Glu-A1, Glu-B1, Glu-D1 wich code for highmolecular-weight subunits of glutenin in hexaploid weat, 11, 29-35.

Popierielia, Fh. A. (1989). Gliadin polymorphism and its relationship with grain quality, productivity and adaptive properties of soft wheat varieties. Moskva: "Agropromizdat", 138-150 (in Russian).

Qaseem, M.F., Qureshi, R., Muqaddasi, Q.H., Shaheen, H., Kousar, R., Röder, M.S. (2018). Genome-wide association mapping in bread wheat subjected to independent and combined high temperature and drought stress. PLoS One, 13. doi: 10.1371/journal.pone.0199121

Rogozhin, V.V., Rogozhina, T.V. (2913). Workshop on the physiology and biochemistry of plants. Petersburg: GIORD, 352 (in Russian). Sallam, A., Alqudah, A. M., Dawood M. F. A., Baenziger P. S., Börner A. (2019). Drought stress tolerance in wheat and barley: advances in physiology, breeding and genetics research. International Journal of Molecular Sciences, 20(13), 31-37. doi: 10.3390/ijms20133137

Sharma, P., Sareen, S., Saini, M. (2017). Assessing genetic variation for heat stress tolerance in Indian bread wheat genotypes using morpho-physiological traits and molecular markers. Plant Genetic Resources, 15, 539-547. doi: 10.1017/S1479262116000241

Sukumaran, S., Reynolds, M. P., Sansaloni, C. (2018). Genome-wide association analyses identify qtl hotspots for yield and component traits in Durum wheat grown under yield potential, drought, and heat stress environments. Frontiers in Plant Science, 9, 81. doi: $10.3389 /$ fpls.2018.00081

Thabet, S.G., Moursi, Y.S., Karam, M.A., Graner, A., Alqudah, A.M. (2018). Genetic basis of drought tolerance during seed germination in barley. PLOS ONE, 13:e0206682. doi: 10.1371/journal.pone.0206682

Tardieu, F., Parent, B., Caldeira, C., Welcker, C. (2014). Genetic and physiological controls of growth under water deficit. Journal of Plant Physiology, 164 (4), 1628-1635. doi.org/10.1104/pp.113.233353

Tishchyenko, V. N., Chyekalin, N. M., Panchyenko, I. A., Didyenko, S. Yu. (2006). Polymorphism glutenins in accessions of Poltava winter wheat breeding. Visnik Poltava State Agrarian Academy, 3, 6 (in Ukrainian).

Tishchenko, V.N., Panchenko, P.M., Chernysheva, O.P. (2013). Identification of varieties and breeding lines of winter wheat by the balance of quantitative traits using cluster analysis. Visnik Poltava State Agrarian Academy, 3, 28-31 (in Russian).

Wei, B., Jing, R., Wang, Ch. (2009). Dreb1 genes in wheat (Triticum aestivum L.): development of functional markers and gene mapping based on SNPs. Molecular Breeding, 23, 13-22. doi: 10.1007/s11032-008-9209-z

\section{Citation:}

Moskalets, V.V., Vovkohon, A.H., Kliuchevych, M.M., Moskalets, T.Z., Sliusarenko, A.O., Liubych, V.V., Martyniuk, A.T., Pushka, O.S., Pushka, I.M., Nevlad, V.I. (2019). Biochemical and molecular-genetic markers of adaptability and quality of genotypes in cultural and wild cereal plants. Ukrainian Journal of Ecology, $9(4), 695-703$. 